\title{
A practical theological approach to the challenge of poverty in post-1994 South Africa: Apostolic Faith Mission as a case study
}

\begin{tabular}{|c|c|}
\hline \multicolumn{2}{|c|}{$\begin{array}{l}\text { Author: } \\
\text { Mookgo S. Kgatle }\end{array}$} \\
\hline \multicolumn{2}{|c|}{ 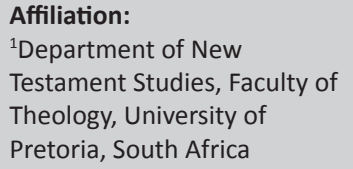 } \\
\hline \multicolumn{2}{|c|}{$\begin{array}{l}\text { Research Project Registration: } \\
\text { Project Leader: E. van Eck } 10 \\
\text { Project Number: } 2400030\end{array}$} \\
\hline \multicolumn{2}{|c|}{$\begin{array}{l}\text { Description: } \\
\text { Dr Kgatle is participating in } \\
\text { the research project } \\
\text { 'Socio-cultural Readings', } \\
\text { directed by Prof. Dr Ernest } \\
\text { van Eck, Department of New } \\
\text { Testament Studies, Faculty of } \\
\text { Theology, University of } \\
\text { Pretoria. }\end{array}$} \\
\hline \multicolumn{2}{|c|}{$\begin{array}{l}\text { Corresponding author: } \\
\text { Mookgo Kgatle, } \\
\text { u10173600@tuks.co.za }\end{array}$} \\
\hline $\begin{array}{l}\text { Dates: } \\
\text { Received: } 20 \text { I } \\
\text { Accepted: } 03 \\
\text { Published: } 20\end{array}$ & $\begin{array}{l}\text { Mar. } 2017 \\
\text { May } 2017 \\
\text { Nov. } 2017\end{array}$ \\
\hline \multicolumn{2}{|c|}{$\begin{array}{l}\text { How to cite this article: } \\
\text { Kgatle, M.S., 2017, 'A } \\
\text { practical theological } \\
\text { approach to the challenge } \\
\text { of poverty in post-1994 } \\
\text { South Africa: Apostolic Faith } \\
\text { Mission as a case study', HTS } \\
\text { Teologiese Studies/ } \\
\text { Theological Studies 73(3), } \\
\text { a4549. https://doi.org/ } \\
\text { 10.4102/hts.v73i3.4549 }\end{array}$} \\
\hline \multicolumn{2}{|c|}{$\begin{array}{l}\text { Copyright: } \\
\text { (c) 2017. The Authors. } \\
\text { Licensee: AOSIS. This work } \\
\text { is licensed under the } \\
\text { Creative Commons } \\
\text { Attribution License. }\end{array}$} \\
\hline \multicolumn{2}{|l|}{ Read online: } \\
\hline 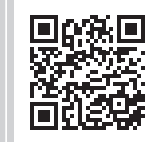 & $\begin{array}{l}\text { Scan this QR } \\
\text { code with your } \\
\text { smart phone or } \\
\text { mobile device } \\
\text { to read online. }\end{array}$ \\
\hline
\end{tabular}

This article demonstrates a practical theological approach to the challenge of poverty in post1994 South Africa by using Apostolic Faith Mission (AFM) as a case study. It argues that while the Reconstruction Development Plan, the Growth Employment and Reconstruction strategy, Accelerated Shared Growth Initiative for South Africa, New Growth Path and the National Development Plan have achieved some level of economic growth, the majority of people in South Africa still live in poverty. To establish this argument, the article starts first by describing the challenge of poverty in post-1994 South Africa. The different economic approaches to the challenge of poverty in post-1994 South Africa are also explained in detail. Lastly, the article elaborates on the ways in which the AFM through its local assemblies can alleviate poverty. The article concludes that the AFM is a collaborator to the post-1994 South African government.

\section{Introduction}

\section{Background}

The discussion on the challenge of poverty in post-1994 South Africa is well documented. According to Mathole (2005:291), poverty is a giant facing the church in South Africa. It affects a large section of the population. It is so widespread throughout the nation that it affects individuals, families, communities and churches both in urban and rural areas. Masango (2014:2) says that the concept of poverty occupies centre stage in South Africa since the dawn of democracy in 1994. Bhorat and Van der Westhuizen (2010:58) note that in the democratic era, growing unemployment rates have been a driver of poverty in South Africa. Poverty has been a challenge since 1994 in South Africa. Van der Westhuizen and Swart (2015:732) add that the South African government views the challenge of poverty alleviation as a key priority. Addressing the problem of poverty has remained one of the primary concerns of the South African government since 1994.

The discussion on different economic approaches to the challenge of poverty in post-1994 South Africa is equally well documented. Lewis (2001:4) explains Reconstruction Development Plan (RDP) as an effective welfare system created to cater for the elderly, disabled, children in need, foster parents and others. Peberdy (2001:26) describes Growth Employment and Reconstruction strategy (GEAR) as a national vision which allows all citizens access to economic and other resources to develop a more balanced society. According to Maree (2007:5), the purpose of Accelerated Shared Growth Initiative for South Africa (ASGISA) was to deal with the vast surplus of low- and intermediate-skilled people by accelerating the rate of economic growth up to 6\% per annum. Kretzschmar (2014:6) outlines the six pillars of the National Development Plan (NDP): unity, active citizenry, growing economy, building capabilities, capable state and responsible leadership.

The article argues that while the above-mentioned economic policies of post-1994 South Africa have achieved some level of economic growth, the majority of people in South Africa still live in poverty. To alleviate poverty, this article studies the Apostolic Faith Mission (AFM) as a collaborator to the post-1994 South African government. This will be achieved by first studying the challenge of poverty in post-1994 South Africa. The different economic approaches to this challenge are also outlined and explained in detail. The purpose of this article is to show the role that the AFM can play through entrepreneurship, inclusivity, moral edification and social relevance to alleviate poverty. It is to show that the AFM can collaborate with the South African government to alleviate poverty. The main aim of this article is to demonstrate that the church is a collaborator to the post1994 South African government. 


\section{Focus}

The focus of this article is the challenge of poverty in post1994 South Africa. Secondly, it is the different economic approaches to the challenge of poverty in post-1994 South Africa. Lastly, it is the ways in which the AFM through its local assemblies can alleviate poverty.

\section{Hypothesis}

The AFM has been dealing with poverty through its social and welfare programmes. This article looks at the ways in which the AFM can collaborate with the South African government to alleviate poverty.

\section{Central argument}

The article argues that while the economic policies of post1994 South Africa, such as RDP, GEAR, ASGISA, NGP and NDP, have achieved some level of economic growth, the majority of people in South Africa still live in poverty. The economic policies of a democratic South Africa, according to Triegaardt (2006:2), are unable to resolve the issue that there are more job-seekers than jobs. Triegaardt continues to say that in failing to address structural unemployment, despite the democratic government's pro-poor policies, its real problem is its lack of vision and direction in comprehensively tackling poverty as a consequence of unemployment. To alleviate poverty, this article studies the AFM as a collaborator to the post-1994 South African government.

\section{Relevance}

This article makes an important contribution to the challenge of poverty in post-1994 South Africa by looking at the ways in which the AFM can collaborate with the post-1994 South African government to deal with poverty. It not only acknowledges the success made by the economic policies of democratic South Africa but also points to the fact that many South Africans still live in poverty. The AFM can come in where the government is failing. This article does not see the AFM as an enemy of the state but as a collaborator to bring better results.

\section{The problem statement}

How can the AFM collaborate with the South African government to address the challenge of poverty in post-1994 South Africa?

\section{The challenge of poverty in post- 1994 South Africa \\ What is poverty?}

Van Rensburg and Breed (2011:3) define poverty as the condition of being extremely poor: beggary, destitution, impecuniosity, impecuniousness, impoverishment, indigence, need, neediness, pennilessness, penuriousness, penury, privation, and/or want. Beyers (2014:2) defines poverty as 'the inability of getting choices and opportunities, a violation of human dignity. It means the lack of basic capacity to participate effectively in society'. Kretzschmar (2014:3) points out that in purely economic terms, poverty can be defined as 'the inability of individuals, households or communities to command sufficient resources to satisfy a socially acceptable minimum standard of living'.

In this article, poverty is defined as the lack of basic needs such as food, education, shelter, water, electricity, medical treatment, sanitation, etc. It must be noted that the lack of any of the basic needs can constitute a state of poverty even if other basic needs are met. For example, a person who has shelter but lacks food can be considered poor. Therefore, in dealing with poverty, the South African government must address all the basic needs in the society. They must give people access to food, shelter, water and sanitation, education, and wellness care.

\section{Types of poverty}

There are different types of poverty: absolute (extreme) poverty, moderate poverty and relative poverty. Absolute poverty implies that households are unable to meet the basic needs for survival. They are chronically hungry, unable to access healthcare, lack the amenities of safe drinking water and sanitation, cannot afford education for some or all children, and perhaps lack rudimentary shelter, and basic articles of clothing such as shoes (Sachs 2005:20). Moderate poverty refers to conditions of life in which the basic needs are met but just barely. Relative poverty is generally perceived to be a household income level below a given proportion of the average national income (Triegaardt 2006:2). In this article, the focus shall be on absolute poverty in post-1994 South Africa.

\section{Recent statistics}

Statistics show that the majority of people in South Africa live in absolute poverty. The picture of poverty in South Africa is overwhelming. Kruidenier (2015:5) points out that just below $50 \%$ of the population belong to the poorest $40 \%$ of the households. In the population, $27 \%$ fall in the bottom $20 \%$ of the households and are classified as 'ultra poor'. In addition, $56 \%$ of black people in South Africa are below the poverty line, while $60 \%$ are adult females (Molobi 2016:2). Furthermore, recent statistics reveal that $56 \%$ of women in South Africa live in poor households in contrast to $51.8 \%$ of men (Mtshiselwa 2016:1). Poverty remains very high in South Africa, and there is a view that poverty might be increasing particularly as the South African economy is deteriorating further (Gumede 2014:58).

Poverty in South Africa is not confined to one racial or ethnic group but cuts across all groups. The concentration is manifestly higher among black people (Kruidenier 2015:5). Black people clearly continue to account for a much larger share in poverty than their share in the population, with the other race groups, accounting for a considerably smaller 
share of poverty relative to their population weight. By way of contrast, white people account for less than $1 \%$ of the poor population, while constituting around $10 \%$ of the population (Bhorat \& Van der Westhuizen 2010:49).

In summary, the majority of people in South Africa still live in absolute poverty and the most vulnerable people are women. Poverty is prevalent among black people whereby many are living below the bread line. Many South Africans had much hope in democracy but are discouraged to discover that 23 years after democracy, they still live under difficult conditions and on empty stomachs. They are discouraged to still teach and learn under trees. They are discouraged to live without clean water and sanitation. They are disappointed because they still live in shacks and in informal settlements without land. The state of poverty in post-1994 South Africa requires a different approach to change the status quo.

\section{Causes of poverty in post-1994 South Africa}

Poverty in South Africa is driven primarily by unemployment among less-skilled workers (Seekings 2014:15). The rate of unemployment is very high such that those that lose their jobs will not be easily employed again. The majority depend on social grants as a result of high rate of unemployment. Consequently, the demand on social grants has a negative impact on the national budget. There is also a problem of employability because the majority of unemployed people are young people or young graduates who lack work experience.

Furthermore, social security facilitates passivity and dependence among the poor, and thus welfare helps perpetuate poverty rather than alleviate it (Potts 2012:78). Since 1994, several key factors have inhibited poverty reduction: the number of unemployed people has increased; current economic policies are not benefitting the poor (except in terms of welfare grants); the lack of organisation at the community level that can affect change; the lack of education; and the negative effects of crime, violence and infectious diseases (Kretzschmar 2014:5).

One of the most far-reaching effects of Apartheid was the role it played in generating extreme poverty in South Africa (Keswell 2004:1). The dispossession by past conquest and subsequent settlement by newcomers with superior resources remains the basis of poverty (Moodley \& Adam 2009:63). In the South African context, the strong inequality between racial groups as a result of apartheid has always been a significant driver of poverty (Bhorat \& Van der Westhuizen 2010:57). Because of the country's history of racial discrimination and forced segregation, poverty has a strong association with race and place, which creates additional distance between the poor and the rich (Du toit \& Nkomo 2014:2). The historical exclusion of the majority of citizens from sharing the country's wealth and opportunities created structural rifts that would take decades to mend. In consequence, chronic poverty persists in the midst of wealth and prosperity (Ncube, Shimeles \& Verdier-Chouchare 2012:8).

These high levels of poverty have a historical basis in apartheid and are driven principally by the fact that too few people work and that the quality of education for many black people remains poor (Malakwane 2012:12).The system of apartheid was predicated on ensuring that these inequalities were structured along racial lines. Under apartheid, building on decades of segregation and colonial rule, four racially classified population groups were legislatively maintained: white people, mixed race, Asian and black people. From 1948, all South Africans not designated 'white' were denied democratic participation, and state resources were allocated differentially for services such as education and health. Over time, the formal imposition of apartheid from 1948 accelerated the wealth gap between population groups (Graven 2014:1041).

While it is true that the apartheid is one of the major causes of poverty, the democratic government cannot continue to blame apartheid system because that system is no more. After 23 years of democracy, the leaders in a democratic government cannot continue to point people to the past, but they need to point them into the future. The democratic government should be responsible and accountable for its own action and consequences. The next generation will judge the democratic leaders by their words and actions, not apartheid. The democratic government instead of blaming the past regime should come up with solutions on how to deal with poverty. Hence, this article is about the collaboration between the AFM and the government in a quest to alleviate poverty.

This brings us to another cause of poverty in post-1994 South Africa, corruption. Corruption is taking from the poor. Corruption is not only ethically wrong, but also results in the exploitation, oppression and impoverishment of society and obstructs the service delivery everyone needs, and the poor in particular (Khotseng \& Tucker 2013:5). Corruption is the thief that takes from the poor. Corruption takes the money that was meant to help the poor and enrich the elite. It causes poverty to be chronic without a solution.

Corruption in the public administration and in political decision making is a major enemy of those who wish to make a genuine effort to tackle the challenge of poverty. Corruption has the capacity to render any society unstable and insecure. When corruption becomes endemic it is destructive of the achievement of the type of society that was envisaged by the founders of the new South Africa. Corruption is a cancer in any society. Left unchecked and unchallenged corruption leads to failed state status and with that the further exacerbation of poverty (Accountability now 2012).

Global Financial Integrity said in a report that South Africa had suffered an illegal outflow of R185-billion due to corruption in the public sector between 1994 and 2008 
(News24 2012). It has been estimated that R30 billion per year, which is $20 \%$ of the overall government procurement budget of R150 billion, is being lost or is disappearing into corruption (Africa check 2015). This means that South Africa could have lost more than R700 billion in the last 23 years. Money lost due to government corruption could have been used to better the lives of all South African citizens, especially the poor.

\section{Various approaches to the challenge of poverty in post-1994 South Africa}

There has been an attempt by the post-1994 South African government to address the challenge of poverty. There have been different economic approaches to this challenge. The economic approaches include the RDP, the GEAR, ASGISA, NGP and the NDP. To address the glaring inequities in the economy and revive growth prospects, the South African government established RDP in 1994. Funding was to come from reprioritising government expenditure towards redistributive social spending, supplemented by foreign aid and joint-financing deals between the government and the private sector (Bucknell et al. 2002:1). The policy encapsulated 'six cardinal points': 'An integrated programme, based on the needs of people; that provides peace and security for all and builds the nation, links reconstruction and development and deepens democracy' (Aregbeshola 2012:1253).

RDP was a national vision which allowed all citizens access to economic and other resources to develop a more equal society (Peberdy 2001:26). RDP outlined a comprehensive plan to reduce poverty and inequality, emphasised economic growth, as well as efforts to improve service delivery and human resource development for previously disadvantaged groups (Malakwane 2012:35). It proposed growth and development through reconstruction and redistribution, sought a leading and enabling role for the government in guiding the mixed economy through reconstruction and development, and argued for a living wage as a prerequisite for achieving the required level of economic growth (Adelzadeh 1996:66).

RDP became a success on one level; Lewis (2001:4) states that 'under this economic policy an effective welfare system was created to cater for the elderly, disabled, children in need, foster parents and others'. The only problem is that it only focused on the social responsibilities of the state but did not create jobs to deal with poverty on a permanent basis. Seekings (2014:4) adds that the RDP failed to empower the poor to seize opportunities to develop to their full potential and to sustain themselves through productive activity, with the state ensuring improved access to social security, public education, and other services.

GEAR policy framework was devised as an instrument for building and restructuring the economy by addressing the failings of the RDP. GEAR was designed as an integrated economic strategy capable of expiating challenges that subjugated the achievements of the RDP, such as meeting basic needs, developing human resources, increasing participation in the democratic institutions of civil society and implementing the RDP in all its facets (Aregbeshola 2012:1254).

The first objective of the GEAR programme was achieving macroeconomic balance in the South African economy, that is a reduced budget deficit and the falling rate of inflation. The second objective was to make the South African economy get on a $6 \%$ growth path by 2000 . Improved performances in fixed investment and non-gold exports were meant to propel this growth path. The third objective was redistribution through job creation, realised from the economic growth and labour market reforms (Khamfula \& Draft 2004:2).

GEAR advocated a conventional economic strategy whereby fiscal austerity, wage restraint, financial discipline, the reduction of corporate taxes, and the opening of the economy to capital flows would attract the foreign investment needed to stimulate growth and increase employment (Guy 2004:74). GEAR proposed trade liberalisation, labour market deregulation, and privatisation along with fiscal caution (Seekings 2014:24). The aim of the government with GEAR was to seek a competitive fast-growing economy which creates sufficient jobs for all job-seekers' and 'a redistribution of income and opportunities in favour of the poor'. To this end, it developed an 'integrated strategy' which was designed to attain 'a growth rate of 6 per cent per annum and job creation of 400000 per annum by the year 2000' (Maree 2007:2).

Lewis says that it was able to reduce fiscal deficits, lowering inflation, maintaining exchange rate stability, decreasing barriers to trade and liberalising capital flows (Lewis 2001:4). GEAR was also an endeavour to ensure more efficient coordination of policy. These efforts involved participants from all key government departments and was endorsed by Cabinet and introduced in Parliament by (then) Deputy President Thabo Mbeki as the 'central compass' that would guide all other government programmes (Malakwane 2012:36). There are in fact two problems with GEAR. The first problem is that it did not create jobs. The second problem is that the $6 \%$ economy growth could not be reached, not even close. This is the major reason of the failure of GEAR.

GEAR policies and reforms supported monetary policy after 1996, helping to bring inflation down further and keep it there. The reduction in the fiscal deficits and public sector borrowing was made possible by the reduced growth in government consumption spending and stricter tax collection and administration (Hodge n.d.:7). With GEAR, the South African government stressed fiscal and monetary discipline, acknowledging the limitations of government policy in stimulating growth and recognising that the market would have to play a major role in rebuilding the economy (Bucknell et al 2002:2).

GEAR was replaced by ASGISA, which was aimed at reducing poverty, inequality and unemployment. In particular, ASGI 
aimed at reducing the high levels of unemployment and poverty - both via the general 'trickle down' effects of sustained high growth and more directly by greatly expanding the government investment spending on the country's infrastructure (Hodge n.d.:3). ASGISA aimed at improving policy implementation and economic growth by dealing with the following challenges: lack of skilled and committed staff in the public service, lack of human resource to implement policies inadequate financial resources corruption and mismanagement of funds, lack of people-driven development, lack of proper co-ordination between institutions, barriers to entry, limits to competition and limited new investment opportunities (Southern African Catholic Bishops Conference 2006). ASGISA was short-lived because of the removal of Thabo Mbeki in 2008.

NGP recognised that structural unemployment remains extremely high; poverty continues to afflict millions; oppression of workers continues. In this regard, the NGP was envisioned to accelerate growth in the South African economy, and to do so in ways that rapidly reduce poverty, unemployment and inequality. To help overcome these structural challenges and contribute to the achievement of higher levels of economic growth, NGP was seen as a necessary policy (South African History online 2014). The NGP identified where employment creation was possible, both in economic sectors as conventionally defined and in cross-cutting activities. It then analyses the policies and institutional developments required to take advantage of these opportunities (Malakwane 2012:47).

Over and above RDP, GEAR, ASGISA and NGP, according to Gumede (2013:23), are new visions for South Africa's political economy NDP. In support of the NDP, Kretzschmar (2014:6) highlights its six pillars: 'to unite all South Africans around a common programme to fight poverty and inequality and to foster a spirit of unity'; an active citizenry; a growing and inclusive economy; to build capabilities; a capable and developmental state; 'the responsibilities of leadership throughout society to work together to solve our problems' (Kretzschmar 2014:6). The NDP planned to create jobs by improved economic policy, public/private partnerships, the promotion of investment in labour-intensive economic sectors, improving competitiveness, promoting export, improving labour market functionality, and improving skills linked to the requirements of a business (Meyer 2014:74).

NDP is a great idea and can enhance inclusive growth to create jobs and alleviate poverty. The only problem faced by the NDP is the implementation of the programme. There is no political will to put these plans into action given the fact that South Africa has a high level of corruption. Another challenge to its implementation is the culture of cadre deployment practised by the ruling party. This means that people can keep their jobs even if they are not performing because they are connected to the higher powers.

The key economic policies of post-1994 South Africa have achieved some level of growth but have shortcomings.
Hence, the challenge of poverty continues to haunt the South African democratic government. The RDP only focused on social responsibilities of the state but did not create jobs. Although GEAR has been successful in cutting government expenditure, it has failed to deliver on promised jobs and socio-economic opportunities for the poor people in post1994 South Africa. ASGISA was short-lived by the removal of Thabo Mbeki in 2008, but there is no proof that it was going to be a different economic policy. NDP has already been tested by corruption and maladministration.

In his 2017 state of the nation address, the president of the Republic of South Africa Jacob Zuma spoke about radical economic transformation (SONA 2017). This sounds like another economic approach in addition to the economic policies highlighted above. The question is does South Africa need another economic approach or is about the implementation of the already good policies that the country has. This article opines that it is about the implementation of policies than to keep on introducing new approaches that are not implemented. In order for such policies to be implemented there is a need for AFM to collaborate with government.

\section{Practical theological approach to poverty \\ The approach of Apostolic Faith Mission to poverty}

The AFM is a Pentecostal Christian church founded by American missionaries, John G. Lake and Thomas Hezmalhach, in 1908. With 1.2 million adherents, it is South Africa's largest Pentecostal church and the fifth largest religious grouping in South Africa, representing 7.6\% of the population (Kgatle 2016:2). The AFM has been involved in poverty alleviation to a certain level. Wealthy assemblies take care of poor assemblies. Through its welfare department, the church takes care of orphans and the elderly.

The AFM has a programme called uMephi. This is one of their national flagship projects, launched to deal with children in distress. This project deals with the following groups: Street children - these are the children who come to the uMephi shelter after being taken off the streets. Maltreated and sexually abused children - these are the children who have been victims of physical or emotional maltreatment and neglected by their families. Abandoned children - this group consists of children who have been abandoned by their parents in hospitals, many of whom soon after birth. Infants saved from abortion through one of their programmes, Africa Cares for Life, they run pregnancy care/crisis centres and homes for unwed mothers. This programme enables them to assist pregnant unwed mothers who have not opted for abortion but have chosen to save their babies. They provide support to them and assist them in dealing with their decision to save their babies. In response to the increasing social problems of orphans with AIDS, the AFM is running a programme, 'AIDS orphans', to help these children (Burger \& Nel 2008:467). 
The AFM, according to Mathole (2005:254), has an extensive national welfare programme that is driven by local congregations in their communities and supported by their national office. The AFM has established a National Welfare Council that promotes the vision of ministry to the poor within their denomination and backs projects that are run locally through various local congregations. Mathole (2005:258) continues to say that the AFM has not reached a point yet where they can say they have done enough. But they have made a significant difference to the lives of the poor. Because of the high levels of poverty in communities they still have a long way to go. They are making a meaningful contribution at a local church level with their various local church-driven programmes.

This article looks at the ways in which the AFM can further collaborate with the government in a correct way in order to eradicate poverty. The article looks at the ways in which the AFM can become an entrepreneurial church through sowing, sharing, storing and selling in order to fight unemployment that causes poverty. In addition, the article looks at the ways in which the AFM can become an inclusive church in order to fight exclusivity that also causes poverty. Furthermore, the moral AFM can collaborate with government to fight corruption. It explores the ways in which the AFM can become a socially relevant church.

The AFM local assemblies should be in the best position to have the most significant impact on the needs of poor communities, because the local assembly is the closest infrastructure to the context. When working with communities, accurate information of the context is indispensable (Van Rensburg \& Breed 2011). The local assembly is well located within the community to play a central role in the deliberate and targeted assistance provided for the most deprived (Tenai 2016:9). Local assembly initiatives can assist members of their own congregations and families connected with the church. Even though the local assembly does not have resources or power of the state, it can make small-scale, practical contributions to reducing poverty as a witness to its calling to serve others (Kretzschmar 2014:8).

\section{Ways of collaborating with South African governmen}

\section{Entrepreneurship}

The AFM needs to be an entrepreneurial church in order to alleviate poverty. To be entrepreneurial, the AFM according to Molobi (2016:4) should fulfil four responsibilities: sowing, sharing, storing and selling. The sowing church is the handson church whose symbols on the letterhead are 'seed and plough'. This means that the AFM local assemblies can collaborate with the government by being hands-on. The local assemblies in the rural areas, for example, can engage on agricultural projects to alleviate poverty. This kind of projects can employ many women from the local assembly on the one hand and deal with hunger on the other.
The sowing church creates jobs rather than to seek for them. The members of the AFM can become job creators instead of being job-seekers. The working members of the AFM can use part of their income to start businesses and create more jobs. In order to address the issue of employability, the infrastructure in local assemblies can occasionally be utilised as skills development and training centre for the unskilled population. The AFM graduates can teach the unemployed basic skills like communication, computer, customer service, organisational, mathematical, problem solving etc. The unemployed graduates will in turn gain work experience and increase their chances of getting a formal job.

The sharing church sets itself as the people's feeder. This is the type of the church in the book of Acts. According Acts 2:44-45, all that believed were together and had all things common, and sold their possessions and goods, and parted them to all men, as every man had a need (Ac 2:44-45). The AFM should become a sharing church that will share with the people who are in need in the community. The local assemblies in the AFM should start the Soup Kitchen projects to feed those who are hungry. The community will perceive the AFM not as the church that takes from them but as the church that gives to them.

The storing church is the church that determines itself as acting as the part of the food watchman. Most assemblies in the AFM have buildings that they can use to store food so that the food can be used in the times of need. Furthermore, the AFM can teach its members to save food instead of wasting it. This is the strategy of Joseph, who, during the time of abundance, was able to save food that was used during famine. The house of God, according to Malachi 3:10, is called a storehouse. God says bring tithes in the storehouse so that there may be food. It is not to make pastors rich but to reserve food for those that need it most, the poor.

The selling church is one that engages directly with the food business. This is the centre of entrepreneurship. Proverbs 11:26 says that they that withhold corn, the people shall curse them: but blessing shall be upon the head of them that sells it. In this context, the blessing shall be upon the AFM and its local assemblies as they engage in business to help the poor. The members of the local assemblies who are not working can become volunteers in the selling business. The profit of such business can be directed to assist the poor people in and outside the AFM.

\section{Inclusivity}

Racial segregation is one of the causes of poverty highlighted in this article. The AFM united in 1996 after more than eighty years of racial segregation (Kgatle 2015:219). The reality is that the society remains polarised even after 23 years of democracy. Racial comments are posted on social media time and again. The AFM needs to be an inclusive church in order to deal with poverty in post-1994 South Africa. The AFM needs to preach a gospel of inclusivity that affords all 
citizens economic opportunity without looking at colour, age, gender and other categories of discrimination.

Inclusive AFM will ensure that everyone in a particular community or society can participate in forums and processes and have the same access to opportunities (Van der Westhuizen \& Swart 2015:742). The AFM has to start by eradicating any hindrances to the freedoms endowed by God to humanity. Barriers on the basis of gender, age, sexual orientation, race, class, ability, et cetera have to be eradicated. The AFM has to be a place where everyone is an equal member, enjoying all privileges of membership (Tenai 2016:8). There should be the equitable sharing of economic opportunities amongst all its members.

The AFM needs to support inclusivity in order to fight poverty. Inclusivity is a collaborator to the economic policies of the post-1994. Inclusivity creates economic opportunities for a great majority of the country's working age population, and reduces poverty (World economic forum 2015:2). Inclusivity ensures that everyone can participate in the growth process, both in terms of decision-making for organising the growth progression as well as in participating in the growth itself (Ranieri \& Ramos 2013:6).

Inclusive AFM will deal with the idea that economic growth is important but not sufficient to generate sustained improvements in welfare, unless the dividends of growth are shared fairly among individuals and social groups. Inclusive AFM will recognise that in addition to income and wealth, people's well-being is shaped by non-income dimensions, such as their health and education status. The level and distribution along these non-income dimensions are therefore key aspects of Inclusivity, making it a multidimensional concept (Meeting of the OECD Council 2014). Inclusive AFM will ensure lower levels of social turbulence in the post-1994 South Africa. It will change the current recourse of divisive rhetoric (Cilliers \& Aucoin 2016:15).

In summary, inclusive AFM can overcome poverty because everyone will be part of the growth regardless of their economic class, gender, sex, disability and religious affiliation. Inclusivity takes on long term perspective and focuses on productive employment rather than merely direct income redistribution as a means of increasing income for excluded groups. It can equally decrease the high rate of unemployment especially youth unemployment. Inclusivity creates job opportunities for all the citizen of the country.

\section{Moral edification}

Corruption has been identified as another cause of poverty. In order to alleviate poverty the AFM needs to support morality in society. This is done both by modelling these values, teaching them as well as speaking out whenever they are trampled. In the fight against corruption, the AFM has a unique role to play. A large part of our society today looks up to the religious leaders for guidance and advices.
The AFM must stand for the truth when the opportunity presents itself to do so.

The AFM should provide the moral fibres needed in society. AFM can influence the response to poverty by having an ethical impact when principles benefiting all in society are applied within economic systems. They can also influence the response to poverty by fostering an attitude of willingness to practise generosity. The AFM can educate communities in order for human dignity of all in society to be restored. The AFM can be part of the system actively encouraging and participating in alleviating poverty (Beyers 2014:1).

The fight against corruption requires the theological motivation that there is a God to whom humans are accountable. This differentiates a purely humanistic from a religious approach to fight covetousness. A humanistic approach to fight covetousness may be driven by the thought of accountability to other humans; the religious approach is driven primarily by the thought of accountability to God. The guilty person can escape humans, but definitely not God's judgment (Khotseng \& Tucker 2013:7). In this context the AFM needs to point the leaders of society to God. When they go wrong they will face the wrath of God.

In the moral edification of the South African society, AFM can contribute to the establishment of an ethos of human dignity, human rights, reconciliation and peace that can be introduced by civil society into the generalised discourse regarding moral regeneration (Vorster 2015:5). The establishment of an ethos of human dignity can be done by mediating Christ to society. The AFM should concentrate on the transforming power of the kingdom of God in acting out its role in society. It is a call for a kind of intervention that will lead to a change of attitude in society (De wet \& Kruger 2013:2).

There are three suggestions at which the AFM can collaborate with government to fight corruption. The AFM can raise awareness of the problem. This means they do not have to be afraid of government but need to speak the truth. John 8:32 says that you shall know the truth and the truth shall set you free. Secondly, the AFM needs to address the underlying attitude of self-interest and call for social justice. Thirdly, the leadership role of the AFM is imperative in the initiation and facilitation of co-operation in addressing problems. The national office bearers of the AFM must lead by example in this regard (Du Plessis \& Breed 2013:9).

\section{Social relevance}

To deal with poverty, the AFM should be a socially relevant church. The social relevance of the AFM in post-apartheid South Africa could, therefore, be viewed in terms of its ability to assist members at the congregational level to practise their Christian beliefs and calling, thereby contributing to the well-being of members of the society. This includes a focus on economic aspects, healthy citizenship, the development of healthy homes and family life, care for each other, responding and attending to those in need, ensuring that justice is done 
in all areas of life, taking care of the earth, and participating in public debate about issues that affect the well-being of South African people (Van der Westhuizen \& Swart 2015:740).

The AFM should preach the gospel and simultaneously bring development to the community (Wilson \& Letsosa 2014:3). The AFM through local assemblies must delight in the community, in the people surrounding the local assembly, and in each other in the community of faith. The AFM has the responsibility to work for the longevity and healthcare of its inhabitants (James 2015:59). The AFM has to pray against the power of sin that gives rise to injustice, oppression, exploitation and corruption, which ultimately leads to poverty. In doing so, the AFM will help heal the social wounds of the African society and facilitate social transformation (Kakwata 2016:288).

The AFM and the state should join hands and partner together to reach out to the poor. The state should provide what the AFM cannot: money and jobs, and the AFM should provide what the state cannot: feeding the people (Van der Merwe 2014:6).The notion of being 'in solidarity' with the government complemented its prophetic voice where it was critically needed. During the heat of the South African struggle, member churches of the South African Council of Churches could also speak truth to power. The AFM should become a prophetic voice in the midst of absurdity and brighten the way (Kgatla 2016:72).

The AFM should be present in the community by looking after the ill and those without bread. Local assemblies should be present in the community, but they should not be there to make money for themselves; they should be present to reach out to the people, to be there among the people, to help the people, so that they can bring about a new situation for the people in their current situation. They should be present in the community so that they can bring about a new hope for the people (Verster 2015:777).

The AFM and its ministry should allow themselves to be 'interrupted' by the memory of human suffering, as well as the current suffering which challenges the status quo and widens the horizons of our imagination, drawing us into deeper consciousness of, and compassion for, the victims of suffering (Thesnaar 2014:5). The AFM leadership, theologians and pastors, including Christian and development workers, are to accompany and journey with the crucified people (the poor), as they struggle for their own liberation (Buffel 2015:361).

The social involvement of the AFM should not be separated from their witness. It is not a matter of choosing between evangelism and social responsibility. These two are inseparable in the witness of AFM. They should not use their poverty alleviation initiatives as an incentive for the poor to get converted. They should not lure the poor to Christ with these social welfare initiatives. They should be interested in the total welfare of the person. They should model their ministry on Christ. Jesus was good to those who accepted and those who rejected his message (Mathole 2005:259).

\section{Conclusion}

The challenge of poverty has been a thorn in the economy of post-1994 South Africa. A majority of people in South Africa live in poverty. The different economic approaches to this challenge have to a certain extent achieved some levels of growth but failed to alleviate poverty. Reality is that many South Africans still live in absolute poverty and below the bread line. The AFM has played a big role to fight the big giant of apartheid. The AFM has a bigger role to play in dealing with poverty. The AFM should become a collaborator to the South African government.

Many local assemblies in the AFM are already involved in their communities, but they should enhance their involvement by engaging in poverty alleviation projects. They can get more involved by feeding the poor. The AFM should become a selling church. The AFM should become an inclusive church so that economic opportunities will benefit all South Africans, black and white. To fight corruption and other injustices, the AFM should become a moral church. They can alleviate poverty by becoming part of the community in order to experience the pain of the poor. The AFM needs to be a caring local community to take care of the needy until they can take care of themselves.

\section{Acknowledgements Competing interests}

The author declares that he has no financial or personal relationships which may have inappropriately influenced him in writing this article.

\section{References}

Accountability now, 2012, 'The effect of corruption on poverty', viewed 4 September 2012, from www.accountabilitynow.org.za

Adelzadeh, A., 1996, 'From the RDP to GEAR: The gradual embracing of neo-liberalism in economic policy', Transformation 31(4), 66-95.

Africa check, 2015, 'Has South Africa lost R700 billion to corruption since 1994', viewed 30 September 2015, from www.africacheck.org

Aregbeshola, R.A., 2012, 'Decent and coarse forms of political economy: Evidence from South Africa', African Journal of Business Management 6(4), 1252. https:// doi.org/10.5897/AJBM11.671

Beyers, J., 2014, 'The effect of religion on poverty', HTS Teologiese Studies/Theological Studies 70(1), Art. \#2614, 1-8. https://doi.org/10.4102/hts.v70i1.2614

Bhorat, H. \& Van der Westhuizen, C., 2010, 'Poverty, inequality and the nature of economic growth in South Africa', in N. Misra-Dexter \& J. February (eds.), Testing democracy: Which way is South Africa going, pp. 46-70, IDASA, Pretoria.

Bucknell, T., Lee, H., Skuster, P. \& Thornton, M., 2002, Changing GEARs: South Africa and the growth, employment, and redistribution policy of 1996, pubpol 556, viewed 15 April 2002, from www.personal.umich.edu

Buffel, O., 2015, 'Bringing the crucified down from the cross: Preferential option for the poor in the South African context of poverty', Missionalia 43(3), 349-364. https://doi.org/10.7832/43-3-123

Burger, I. \& Nel, M., 2008, The fire falls in Africa, Christian Art, Vereeniging.

Cilliers, J. \& Aucoin, C., 2016, South African scenarios 2024: Politics, violence and growth in the rainbow nation, ISS paper 294, pp. 1-24.

De Wet, F.W. \& Kruger, F.P., 2013, 'Blessed are those that hunger and thirst for righteousness: Sharpening the ethical dimension of prophetic preaching in a context of corruption', Verbum et Ecclesia 34(1), Art. \#722, 1-10. https://doi. org/10.4102/ve.v34i1.722 
Du Plessis, A.L. \& Breed, G., 2013, 'A possible solution for corruption in South Africa with the church as initiator: A practical theological approach', HTS Teologiese Studies/Theological Studies 69(2), Art. \#1298, 1-10. https://doi.org/10.4102/hts. v69i2.1298

Du Toit, B.N. \& Nkomo, G., 2014, 'The ongoing challenge of restorative justice in South Africa: How and why wealthy suburban congregations are responding to poverty and inequality', HTS Teologiese Studies/Theological Studies 70(2), Art. poverty and inequality', HTS Teologiese Studies/Theol

Graven, M.H., 2014, 'Poverty, inequality and mathematics performance: the case of South Africa's post-apartheid context', ZDM 46(7), 1039-1049. https://doi. org/10.1007/s11858-013-0566-7

Gumede, V., 2013, Inclusive development in post-apartheid South Africa, viewed n.d., from www.vusigumede.com/content/2016

Gumede, V., 2014, 'Land reform in post-apartheid South Africa: Should South Africa follow Zimbabwe's Footsteps?' International Journal for African Renaissance Studies 9(1), 50-68. https://doi.org/10.1080/18186874.2014.916877

Guy, J., 2004, 'Somewhere over the rainbow: The nation state, democracy and race in a globalising South Africa', Transformation: Critical Perspectives on Southern Africa 56(1), 68-89. https://doi.org/10.1353/trn.2005.0018

Hodge, D., n.d., Development in the South African economy: from GEAR to ASGISA, some issues for macroeconomic policy, Department of Economics, University of South Africa, Pretoria.

James, G., 2015, 'Urban theology endeavours and a theological vision of hope and justice for post-apartheid South African cities', Stellenbosch Theological Journal 1(2), 43-68. https://doi.org/10.17570/stj.2015.v1n2.a02

Janse van Rensburg, J. \& Breed, J., 2011, 'A structured approach to pastoral care and poverty', Verbum et Ecclesia 32(1), Art. \#490, 1-11. https://doi.org/10.4102/ ve.v32i1.490

Kakwata, F.N., 2016, 'Strategies for dealing with sin in relation to poverty', Stellenbosch Theological Journal 2(2), 273-294.

Kgatla, S.T., 2016, 'Church and South African realities today: Towards a relevan missiology of radical discipleship', Stellenbosch Theological Journal 2(2), 57-75.

Kgatle, M.S., 2015, 'Servant leadership in Mark 10: 35-45 applied to African Pentecostal Christianity', Doctoral dissertation, University of Pretoria.

Kgatle, M.S., 2016, 'Sociological and theological factors that caused schisms in the Apostolic Faith Mission of South Africa', Studia Historiae Ecclesiasticae 42(1), 1-15. https://doi.org/10.17159/2412-4265/2016/1216

Khamfula, Y. \& Draft, F., 2004, Macroeconomic policies, shocks and economic growth in South Africa, Global Development Network, School of Economic and Business Sciences, University of Witwatersrand, Johannesburg, South Africa.

Khotseng, B. \& Tucker, A.R., 2013, 'They worship in our churches' - An opportunity for the church to intervene in order to diminish the corruption that is hindering service delivery in South Africa?', HTS Teologiese Studies/Theological Studies 69(2), Art. \#1933, 1-11. https://doi.org/10.4102/hts.v69i2.1933

Keswell, M., 2004, Education and racial inequality in post apartheid South Africa, Santa Fe Institute Working Paper, Santa Fe, NM.

Kretzschmar, L., 2014, 'An ethical analysis of the implementation of poverty reduction policies in South Africa and Chile and their implications for the Church', HTS Teologiese Studies/Theological Studies 70(1), Art. \#2069, 1-11. https://doi. org/10.4102/hts.v70i1.2069

Kruidenier, R., 2015, 'Trying for better circumstances (Zama Zama): Exploring ubuntu amongst marginalised women in an informal settlement', Verbum et Ecclesia 36(2), Art. \#1433, 1-7. https://doi.org/10.4102/ve.v36i2.1433

Lewis, J.D., 2001, 'Policies to promote growth and employment in South Africa, trade and industry policy strategies', World Bank, Southern Africa Department.

Malakwane, C.T., 2012, 'Economic and social effects of unemployment in South Africa: Prospects for the future', Doctoral dissertation, Tshwane University of Technology.

Maree, J., 2007, Strategies for reducing unemployment in South Africa and the role of organised labour, global labour university conference on labour and the challenges of development, University of Witwatersrand, Johannesburg.

Masango, M.J., 2014, 'An economic system that crushes the poor', HTS Teologiese Studies/Theological Studies 70(1), Art. \#2737, 1-5. https://doi.org/10.4102/hts. v70i1.2737

Mathole, E.M.K., 2005, 'The Christian witness in the context of poverty with special reference to the South African Charismatic Evangelicals, PhD thesis, Department of Science of Religion and Missiology, University of Pretoria.

Meeting of the OECD Council, 2014, Report on the OECD framework for inclusive growth, viewed 7 May 2014, from http://www.oecd.org
Meyer, D.F., 2014, 'Job creation, a mission impossible? The South African case', Mediterranean Journal of Social Sciences 5(16), 65. https://doi.org/10.5901/ mjss.2014.v5n16p65

Molobi, V.M.S., 2016, 'Dealing with poverty, health and maternal child survival: The Organisation of African Independent Churches perspective', Verbum et Ecclesia 37(1), a1521. https://doi.org/10.4102/ve.v37i1.1521

Moodley, K. \& Adam, H., 2000, 'Race and nation in post-apartheid South Africa', Current Sociology 48(3), 51-69. https://doi.org/10.1177/0011392100048003005

Mtshiselwa, V.N.N., 2016, 'Reading Ruth 4 and Leviticus 25:8-55 in the light of The landless and poor women in South Africa: A conversation with Fernando $F$ Segovia and Ernesto 'Che' Guevara', HTS Teologiese Studies/Theological Studies 72(1), a3140. https://doi.org/10.4102/hts.v72i1.3140

Ncube, M., Shimeles, A. \& Verdier-Chouchare, A., 2012, South Africa's quest for inclusive development, Working Paper No. 150, African development bank group, Tunis-Belvedère.News24, 2012, Corruption-South Africa counting the cost, viewed 08 may 2012, from http://www.news24.com

Peberdy, S., 2001, 'Imagining immigration inclusive identities and exclusive policies in post-1994 south Africa', Africa Today 48(3), 14-32. https://doi.org/10.2979/ AFT.2001.48.3.14

Potts, R., 2012, 'Social welfare in South Africa: Curing or causing poverty', Penn State Journal of International Affairs 1(2), 72-90.

Ranieri, R. \& Ramos, R.A., 2013, Inclusive growth: The building up of a concept, International Policy Centre for Inclusive Growth, Brasilia.

Sachs, J., 2005, The end of poverty: Economic possibilities for our time, Penguin, New York.

Seekings, J., 2014, 'South Africa: Democracy, poverty and inclusive growth since 1994', in Democracy Works-Conference Paper. Centre for Development and Enterprise (CDE), viewed 8 April 2014, from http://www.cde.org.Za

SONA, 2017, The state of the national address by the South African government, viewed 09 February 2017, from http://www.gov.za

South African History online, 2014, South Africa-first 20 years of democracy (19942014): South Africa's key economic policies changes (1994-2013), viewed 4 November 2014. from www.sahistory.org.za

Southern African Catholic Bishops Conference (SACBC), 2006, An outline and brief analysis of Asgisa, Briefing paper 156, viewed April 2006, from http://www.sacbc. org

Tenai, N.K., 2016, 'Is poverty a matter of perspective? Significance of Amartya Sen for the Church's response to poverty: A public practical theological reflection', HTS Teologiese Studies/Theological Studies 72(2), a3143. https://doi.org/10.4102/hts. v72i 2.3143

Thesnaar, C., 2014, 'Rural education: Reimagining the role of the church in transforming poverty-stricken South Africa', HTS Teologiese Studies/Theological Studies 70(1), Art. \#2629, 1-7. https://doi.org/10.4102/hts.v70i1.2629

Triegaardt, J.D., 2006, Reflections on poverty and inequality in South Africa: Policy considerations in an emerging democracy, Research Paper, Development Bank of Southern Africa, Midrand.

Van der Merwe, J., 2014, 'The local church as a non-governmental organisation in the fight against poverty: A historical overview of Bethulie 1933-1935', HTS Teologiese Studies/Theological Studies 70(1), Art. \#2617, 1-7. https://doi.org/10.4102/hts. v70i1.2617

Van der Westhuizen, M. \& Swart, I., 2015, 'The struggle against poverty, unemployment and social injustice in present-day South Africa: Exploring the involvement of the Dutch Reformed Church at congregational level', Stellenbosch
1(2), 731-759. https://doi.org/10.17570/stj.2015.v1n2.a35

Van Rensburg, J. \& Breed, J., 2011, 'A structured approach to pastoral care and poverty', Verbum et Ecclesia 32(1), Art. \#490, 1-11. https://doi.org/10.4102/ poverty', Verbun
ve.v32i1.490

Verster, P., 2015, 'Inspiration from the Gospel for the fullness of life in the informal settlements in Mangaung, Free State Province, South Africa', Stellenbosch Theological Journal 1(2), 761-781. https://doi.org/10.17570/stj.2015.v1n2.a36

Vorster, J.M., 2015, 'The possible contribution of civil society in the moral edification of South African society: The example of the "United Democratic Front" and the "Treatment Action Campaign" (1983-2014)', HTS Teologiese Studies/Theological Studies 71(3), Art. \#2754, 1-8. https://doi.org/10.4102/hts.v71i3.2754

Wilson, A. \& Letsosa, R., 2014, 'Biblical principles towards a pastoral strategy for poverty alleviation amongst the youth in Uganda', HTS Teologiese Studies/ Theological Studies 70(2), Art. 1328, 1-7. https://doi.org/10.4102/hts.v70

World economic forum, 2015, Report on the inclusive growth and development, viewed 28 september 2015, from https://inclusive.growthlab.cid.harvard.edu/ blog/wef-2015-inclusive-growth-and-development-report 